\title{
Perceived Organizational Crisis Preparedness of Corporations in Stock Exchange of Thailand 100 (SET 100 Index)
}

\author{
Dr. Chaiyaset Promsri \\ Faculty of Business Administration, Rajamangala University of Technology Phra Nakhon, Thailand \\ Email: Chaiyaset.p@rmutp.ac.th
}

\section{Doi:10.5901/mjss.2015.v6n3p583}

\begin{abstract}
This study examines perceived organizational crisis preparedness of corporations listed in Stock Exchange of Thailand 100 index, and compares the differences on organizational characteristics among these companies. Samples of 300 employees in six companies in different industries listed in SET 100 were purposively selected to participate in this study by using nonprobability sampling approach. Thirty items of self-administrated questionnaires were equally distributed to these six companies. The total of three-hundred questionnaires was returned with completion. The descriptive statistics were used to analyze the level of perceived organizational crisis preparedness, and to compare mean differences of independent variables on perceived organizational crisis preparedness. The results showed that the total mean score of perceived organizational crisis preparedness of respondents was "high." The limitations and further recommendations were also discussed.
\end{abstract}

Keywords: Crisis Preparedness, Crisis Management, Stock Exchange of Thailand, SET 100

\section{Introduction}

To become a successful company in a highly turbulent environment in today's business world, a company must have an ability to cope with uncertainties or unusual situations when they occured. Ability to deal with crises depends on the company's readiness and preparation when confronting with crises. Though various studies have attempted to examine the promptness of crisis management in different settings (Chong \& Nyaw, 2002; Ocal, Oral, \& Erdis, 2006; Fowler, Kling, \& Larson, 2007; Najafbagy, 2011; Johansen, Aggerholm, \& Frandsen, 2012), there is still a few research focusing on preevent preparedness, which is necessary to measure the crisis management process and results (Promsri, 2014). In particular, a study of organizational crisis preparedness in Thailand is limited, and needs to be explored especially companies listed in Stock Exchange of Thailand 100 index (SET 100). Stock Exchange of Thailand has indexed the most effective and efficient corporations based on the following criteria: the period of registration in a stock market (required at least six months), market value and capitalization, the eligible stocks must be actively trade and monthly turnover value must have been more than 50 percent, the ratio of free-float (at least 20\%) (Stock Exchange of Thailand, 2007). Companies listed in Stock Exchange of Thailand 100 index are technically robust in terms of financial performance and profitability. To achieve these goals, listed companies in SET 100 index must be able to manage their organizational resources effectively and efficiently regardless of the types of situations companies confront. To ensure that companies listed in SET 100 index have sufficient capabilities to deal with unusual circumstance, organizational crisis preparedness is needed to be measured. Moreover, the previous research indicated that demographic and organizational factors including respondent's gender, respondent's position in organization, number of employees, respondent's employment state, level of education, work experience (years), type of industry, and education in crisis management had influenced on companies' crisis preparation and management (Chong \& Nyaw, 2002; Fowler, Kling, \& Larson, 2007; Johansen, Aggerholm, \& Frandsen, 2012). Therefore, this study aims to examine perceived organizational crisis preparedness of corporations listed in SET 100, and to compare the differences on organizational characteristics among these companies.

\subsection{Research Questions}

1. What is level of perceived organizational crisis preparedness of corporations listed in SET 100 ?

2. What are differences on perceptions of organizational crisis preparedness of corporations listed in SET 100 in terms of basic characteristics of the organizations? 


\section{Literature Review}

After reviewing related concepts and research on crisis management, this present study developed the conceptual framework that was consistent with the research objectives. The variables appeared on conceptual framework were created based on the literature review, as shown in Table 1. Independent variables were developed based on the works of Chong and Nyaw (2002); Fowler, Kling, and Larson (2007); and Johansen, Aggerholm, and Frandsen (2012). Independent variables included 'Respondent's gender', 'Respondent's position in organization', 'Number of employees', 'Respondent's employment state', 'Level of education', 'Work experience (years)', 'Type of industry', and 'Education in crisis management.'

Perceived organizational crisis preparedness was determined as dependent variable in this study. Perceived organizational crisis preparedness was described the understanding, confidence, and familiarity of organization's preparation based on employees' perceptions. This variable was developed based on the works of Fowler, Kling, and Larson (2007); Dinkin (2007); and Bernstein (2012).

Table 1. Research variables

\begin{tabular}{|c|c|c|c|}
\hline Variables & Brief description & Authors & $\begin{array}{l}\text { Dependent (D)/ } \\
\text { Independent (I) }\end{array}$ \\
\hline $\begin{array}{l}\text { Organizational and } \\
\text { Demographic Variables }\end{array}$ & $\begin{array}{l}\text {-Respondent's gender } \\
\text {-Respondent's position in organization } \\
\text { - Number of employees } \\
\text {-Respondent's employment state } \\
\text { - Level of education } \\
\text { - Work experience (years) } \\
\text { - Type of industry } \\
\text {-Education in crisis management }\end{array}$ & $\begin{array}{l}\text { Fowler, Kling, \& Larson (2007) } \\
\text { Chong \& Nyaw (2002) } \\
\text { Johansen, Aggerholm, \& } \\
\text { Frandsen (2012) }\end{array}$ & $\begin{array}{l}\text { Independent } \\
\text { Independent } \\
\text { Independent }\end{array}$ \\
\hline $\begin{array}{l}\text { Perceived } \\
\text { Organizational Crisis } \\
\text { Preparedness }\end{array}$ & $\begin{array}{l}\text { Perceived organizational crisis preparedness are } \\
\text { described the understanding, confidence, and } \\
\text { familiarity of organization's preparation based on } \\
\text { employees' perceptions. }\end{array}$ & $\begin{array}{l}\text { Fowler, Kling, \& Larson (2007); } \\
\text { Dinkin (2007), Bernstein (2012) }\end{array}$ & Dependent \\
\hline
\end{tabular}

\section{Methodology}

A survey research design was used to answer the research questions in this study. The research design of this study involved a comparison of perceived organizational crisis preparedness of companies listed in SET100.

Independent variables of this study were gender, position in organization, number of employees, respondent's employment state, level of education, work experience (years), type of industry, and education in crisis management.

Dependent variable of this study was perceived organizational crisis preparedness.

\subsection{Sampling Plan}

Participants consisted of a total of 300 employees from six companies in six different industries listed in SET 100. According to the criteria of Stock Exchange of Thailand, the industry was divided into eight different industries including agricultural industry, financial industry, property and construction industry, resource industry, service industry, consumption industry, industrial industry, and technological industry. However, there were a few companies in consumption and industrial industries listed in SET 100 index, and after contacting the companies in these two industries, they denied to participate in this study. Therefore, there were only six industries including agricultural industry, financial industry, property and construction industry, resource industry, service industry, and technological industry left for data collection. This study was used purposive sampling to select the companies due to the availability and accessibility of the companies. To improve the sample representativeness, questionnaires were distributed based on organizational size. Large organization with more than 1,000 employees received 50 copies. In this study, most of purposively selected companies listed in SET 100 were large corporations. Thus, each company was sent 50 copies of questionnaire equally. The researcher and the research assistant contacted the HR managers of each company in a different industry to distribute the questionnaires to employees. To ensure that each company could return all completed 50 copies to the researcher, the instruction of doing a questionnaire was explained to the HR managers of each company before they 
distributed the questionnaires. Overall, the total of 300 questionnaires of each company in six different industries was returned to the researcher by posted mail with completion.

\subsection{Data Collection}

Data were collected in six large corporations in six different industries including agricultural industry, financial industry, property and construction industry, resource industry, service industry, and technological industry. Questionnaires were equally distributed to HR managers of each company by mail. To ensure the receipt of questionnaires, HR managers of each company were contacted to recheck whether they had received the questionnaires yet. Prior to the questionnaire completion, the researcher and research assistants contacted the representatives of each company to explain the purpose of the study and confirmed the rights protection of subjects. Participants were asked to complete the questionnaire by assessing their degree of agreement based on their perceptions towards organizational crisis preparedness. The researcher asked HR managers of each company to check the completion of each returned questionnaire and the research assistant rechecked again before processing data analysis. Collected data were analyzed using only descriptive statistics to answer two research questions as the non-probability sampling was used.

\subsection{Instrumentation}

A perceived organizational crisis preparedness scale was developed based mainly on a 21-item crisis/ disaster preparedness scale created by Fowler, Kling, and Larson (2007) with their permission. Their scale covered five key areas of crisis including secondary terrorist attack, natural disaster, major terrorist attack, accidental disaster, and workplace violence. Additionally, the relevant concepts of organizational crisis preparedness from Dinkin (2007) and Bernstein (2012) were included as additional items in a modified scale. A rationale of adding additional items was to ensure that some dimensions such as training and support of external agencies were included as part of organizational crisis preparedness. Additional items included item\#22-30, according to Table 2. A total of 30-item for a perceived organizational crisis preparedness questionnaire was finalized and tested for validity and reliability. To ensure the meaning of each item when translated into Thai language, a reversed translation was done by a professional translator. In addition, the index of item-objective congruence (IOC) was used to evaluate the content validity of each item of the scale. A total of five experts in related fields were asked to evaluate the score for each item. The IOC score of more than 0.5 was acceptable. For this instrument, there was no item received a score less than 0.5 .

A final version of perceived organizational crisis preparedness scale comprised of 30-item with a 4-point rating scale (1-4). Participants were asked to rate each item of scale to the extent in which each characteristics described them properly. The rating scale of perceived organizational crisis preparedness scale were $1=$ "strongly disagree", $2=$ "disagree", 3 = "agree", and 4 = "strongly agree". This instrument had a Cronbach's alpha of 0.94, which was highly acceptable. Criteria used to interpret mean scores was determined by calculating the interval class as follows: maximum score - minimum score/ number of levels. Thus, the mean scores interpretation can be categorized to 4 levels as follows:

Mean scores between $3.26-4.00=$ strongly agree (Vey high)

Mean scores between $2.51-3.25=$ agree (High)

Mean scores between $1.76-2.50=$ disagree (Low)

Mean scores between $1.00-1.75=$ strongly disagree (Very low)

\section{Findings}

As of 300 questionnaires distributed to six companies in different industries listed in Stock Exchange of Thailand 100 index (informally called SET 100), all of them were returned with completion. The Demographic and Organizational characteristics provided information about the background of each respondent. Personal and organizational factors of sample respondents showed that more than a half of respondents were female (57\%). The majority of respondents' employee position was nonmanagement (74\%). For number of employees, the largest group of respondents stated that their companies had more than 6,000 employees (64.2\%). Regarding organizational size, some employees may be confused while filled out this question as they might have thought about the total number of employees of the holding company or the total number of employees in their working companies under the management of the holding company. For employment state, the majority of respondent was employee (80.3\%). Personal and organizational factors of sample respondents presented that the largest group of respondents was educated in "undergraduate degree" level (63.3\%). Almost a half of respondents had approximately 1-10 years of working experience (48\%). For type of industry, as each 
company had 50 employees completed the survey questionnaire, the number of each industry was therefore equal, which was about $16.7 \%$ out of a hundred. For education in crisis management, most of respondent was provided education about crisis (74.3\%).

Table 2. Mean and Standard Deviation for Perceived Organizational Crisis Preparedness ( $n=300)$

\begin{tabular}{|c|c|c|c|c|}
\hline Items & Mean & S.D. & Level & Ranking \\
\hline 1) I am very familiar with our company's evacuation plan & 3.11 & .614 & High & 17 \\
\hline $\begin{array}{l}\text { 2) My organization has provided each employee with a basic emergency preparedness kit (e.g., } \\
\text { flashlight, smoke mask, etc.) }\end{array}$ & 3.22 & .584 & High & 6 \\
\hline 3) The security at my workplace is adequate. & 3.24 & .610 & High & 4 \\
\hline $\begin{array}{l}\text { 4) If a crisis occurred at my organization, I am familiar with the plan for how family members can get } \\
\text { information on the status (e.g. safety) of their relatives. }\end{array}$ & 3.00 & .649 & High & 25 \\
\hline $\begin{array}{l}\text { 5) In the event of an emergency or disaster, I am familiar with my organization's plan to continue } \\
\text { operations from another location. }\end{array}$ & 2.94 & .767 & High & 29 \\
\hline 6) All organization suffered a serious crisis; I would still have my job. & 3.07 & .766 & High & 22 \\
\hline $\begin{array}{l}\text { 7) If my organization suffered a crisis, I would still be covered by my organization's employee benefits } \\
\text { (e.g. health insurance, etc.) }\end{array}$ & 3.24 & .631 & High & 3 \\
\hline $\begin{array}{l}\text { 8) Security at my workplace has been significantly increased since the anti-government } \\
\text { demonstration occurred. }\end{array}$ & 3.19 & .563 & High & 9 \\
\hline 9) I know where the nearest fire extinguisher is to my desk/ workstation. & 3.11 & .632 & High & 14 \\
\hline $\begin{array}{l}\text { 10) If a crisis and evacuation occurred at my organization, I am familiar with our plan on how to } \\
\text { communicate with my fellow employees from scattered or emergency locations (such as cell phone } \\
\text { numbers, websites, or e-mail lists). }\end{array}$ & 3.07 & .635 & High & 24 \\
\hline 11) Most of our employees are familiar with my organization's crisis/ disaster plan. & 2.97 & .696 & High & 27 \\
\hline $\begin{array}{l}\text { 12) As part of our emergency plan, customers and suppliers would be able to contact us for } \\
\text { information. }\end{array}$ & 2.97 & .633 & High & 28 \\
\hline $\begin{array}{l}\text { 13) If my organization suffered a crisis/ disaster, I would have the data I need to do my job backed up } \\
\text { at a remote site. }\end{array}$ & 3.10 & .711 & High & 18 \\
\hline $\begin{array}{l}\text { 14) My organization offers to pay to have volunteer employees trained in basic life support } \\
\text { techniques, such as CPR, first aid, etc. }\end{array}$ & 3.11 & .619 & High & 16 \\
\hline $\begin{array}{l}\text { 15) My organization has contingency plans in place so our customers would be covered if we suffered } \\
\text { a disaster. }\end{array}$ & 3.21 & .552 & High & 7 \\
\hline 16) I know where the nearest emergency exits are to my desk/ workstation. & 3.29 & .588 & $\begin{array}{l}\text { Very } \\
\text { High }\end{array}$ & 2 \\
\hline $\begin{array}{l}\text { 17) My organization's emergency plan has been coordinated with local agencies, such as the fire } \\
\text { department, hospitals, etc. }\end{array}$ & 3.22 & .596 & High & 5 \\
\hline $\begin{array}{l}\text { 18) All organization members are required to rehearse portions of our crisis plan, for example, } \\
\text { evacuation. }\end{array}$ & 3.29 & .633 & $\begin{array}{l}\text { Very } \\
\text { High }\end{array}$ & 1 \\
\hline 19) It would be easy for a potentially threatening nonemployee to gain access to my workplace.(R) & 2.93 & .882 & High & 30 \\
\hline 20) If organization suffered a & 2.99 & .812 & High & 26 \\
\hline 21) Every employee knows what his or her job is when cert & 3.10 & .620 & High & 20 \\
\hline 22) All employees would be provided orientation or refresher training relating to crisis management. & 3.10 & .669 & High & 19 \\
\hline $\begin{array}{l}\text { 23) My organization's current plan is regularly updated based on changes in the organization as well } \\
\text { as by periodic brainstorming session about vulnerabilities. }\end{array}$ & 3.15 & .583 & High & 12 \\
\hline 24) My organization's current plan was prepared by professionals in related fields of crisis/ disaster. & 3.20 & .561 & High & 8 \\
\hline 25) My organization considers the $\mathrm{e}$ & 3.17 & .591 & High & 11 \\
\hline 26) My organization conducts training and simulation about crisis for all employees & 3.12 & .693 & High & 13 \\
\hline 27) My organization has a backup for all data when crisis occurred. & 3.17 & .617 & High & 10 \\
\hline $\begin{array}{l}\text { 28) Employees would be provided knowledge about crisis/ disaster through the internet and intranet } \\
\text { system. }\end{array}$ & 3.09 & .691 & High & 21 \\
\hline $\begin{array}{l}\text { 29) My organization collaborates with internal agencies for developing activities that relate to crisis } \\
\text { preparedness. }\end{array}$ & 3.11 & .623 & High & 14 \\
\hline $\begin{array}{l}\text { 30) My organization has a handbook of crisis/ emergency management plan and all employees know } \\
\text { where to get this information. }\end{array}$ & 3.07 & .648 & High & 23 \\
\hline Total & 3.11 & \begin{tabular}{|l|}
.397 \\
\end{tabular} & High & \\
\hline
\end{tabular}

To answer research question \# 1, Table 2 showed the summary of the results of perceived organizational crisis 
preparedness of respondents from six companies in different industries listed in SET100. The total mean score of perceived organizational crisis preparedness of respondents was "high" ( $M=3.11$, S.D. $=.397)$. To consider each item from the highest mean scores to the lowest mean scores, the findings indicated that item\#18 "All organization members are required to rehearse portions of our crisis plan, for example, evacuation" was perceived in a very high level ( $M=3.29$, S.D. $=.633)$. The second highest mean score was item\#16 "I know where the nearest emergency exits are to my desk/ workstation" ( $M=3.29$, S.D. = .588). For the lowest mean scores, the findings showed that item\#19 "It would be easy for a potentially threatening nonemployee to gain access to my workplace" was perceived "low" (M = 2.93, S.D. = .882). The second lowest mean score was item\#5 "In the event of an emergency or disaster, I am familiar with my organization's plan to continue operations from another location" (M = 2.94, S.D. = .767).

Table 3. Compare Mean Differences among Demographic and Organizational Characteristics Variables for Perceived Organizational Crisis Preparedness $(n=300)$

\begin{tabular}{|c|c|c|}
\hline Demographic and Organizational Characteristics Variables & Mean & S.D. \\
\hline $\begin{array}{c}\text { Gender } \\
\text { Male } \\
\text { Female }\end{array}$ & $\begin{array}{l}3.10 \\
3.12\end{array}$ & $\begin{array}{l}.392 \\
.402\end{array}$ \\
\hline $\begin{array}{l}\text { Position in Organization } \\
\text { Top Manager } \\
\text { Middle Manager } \\
\text { First-line Manager } \\
\text { Non-management }\end{array}$ & $\begin{array}{l}3.52 \\
3.34 \\
3.13 \\
3.06\end{array}$ & $\begin{array}{l}.307 \\
.425 \\
.468 \\
.363\end{array}$ \\
\hline $\begin{array}{c}\text { Number of Employees } \\
\text { Less than } 2,000 \\
2,000-4,000 \\
4,000-6,000 \\
\text { More than } 6,000\end{array}$ & $\begin{array}{l}2.79 \\
3.10 \\
3.08 \\
3.11\end{array}$ & $\begin{array}{l}.238 \\
.496 \\
.320 \\
.412\end{array}$ \\
\hline $\begin{array}{l}\text { Employment State } \\
\text { Executives } \\
\text { Employee }\end{array}$ & $\begin{array}{l}3.32 \\
3.06\end{array}$ & $\begin{array}{l}.423 \\
.374\end{array}$ \\
\hline $\begin{array}{c}\text { Level of Education } \\
\text { Lower than Undergraduate Degree } \\
\text { Undergraduate Degree } \\
\text { Graduate Degree }\end{array}$ & $\begin{array}{l}2.97 \\
3.06 \\
3.32\end{array}$ & $\begin{array}{l}.345 \\
.374 \\
.407\end{array}$ \\
\hline $\begin{array}{c}\text { Work Experience } \\
1-10 \\
11-20 \\
\text { More than } 20\end{array}$ & $\begin{array}{l}3.10 \\
3.09 \\
3.20\end{array}$ & $\begin{array}{l}.383 \\
.415 \\
.392\end{array}$ \\
\hline $\begin{array}{c}\text { Type of Industry } \\
\text { Agricultural Industry } \\
\text { Financial Industry } \\
\text { Property and Construction Industry } \\
\text { Resource Industry } \\
\text { Service Industry } \\
\text { Technological Industry }\end{array}$ & $\begin{array}{l}3.27 \\
2.91 \\
3.54 \\
2.98 \\
3.10 \\
2.88\end{array}$ & $\begin{array}{l}.336 \\
.241 \\
.433 \\
.338 \\
.141 \\
.377\end{array}$ \\
\hline $\begin{array}{c}\text { Education in Crisis Management } \\
\text { Provided } \\
\text { Not Provided }\end{array}$ & $\begin{array}{l}3.21 \\
2.82\end{array}$ & $\begin{array}{l}.382 \\
.286\end{array}$ \\
\hline
\end{tabular}

To answer research question \# 2, Table 3 showed mean differences among demographic and organizational variables for perceived organizational preparedness of employees in six companies in different industries. Results found that female $(\mathrm{M}=3.12, \mathrm{~S} . \mathrm{D} .=.402)$ had the same level of perception of organizational crisis preparedness compared to male $(\mathrm{M}=$ 3.10, S.D. = .392). For position in organization, top manager $(M=3.52$, S.D. $=.307)$ had higher perception of organizational crisis preparedness than first-line manager $(M=3.13$, S.D. $=.468)$, and nonmanagement $(M=3.06, S . D .=$ .363), respectively. For number of employees in a specific organization, respondents who worked at the organization with different number of employees had the same level of perception of organizational crisis preparedness. For employment state, findings indicated that executives $(M=3.32$, S.D. $=.423$ ) had a higher perception of organizational crisis 
preparedness than the employee $(M=3.06, S . D .=.374)$. Further, respondents who held graduate degree $(M=3.32$, S.D. $=.407$ ) had higher perception of organizational crisis preparedness than respondents who earned undergraduate degree $(M=3.06, S . D .=.374)$ and below undergraduate degree $(M=2.97$, S.D. $=.345)$, respectively. For work experience, results found that employees with more than 20 years of working experience $(M=3.20$, S.D. $=.392)$ had the same level of perception of organizational crisis preparedness compared to employees with 1-10 years of working experience $(M=3.10, S . D .=.383)$, and employees with $10-20$ years of working experience $(M=3.09, S . D .=.415)$, respectively. To compare mean differences among employees in six companies for different industries, results showed that respondents who worked in property and construction industry $(M=3.54$, S.D. $=.433)$ and agriculture industry $(M=$ 3.37, S.D. $=.326)$ had higher perception of organizational crisis preparedness than service industry $(M=3.10$, S.D. $=$ $.141)$, resource industry $(M=2.98, S . D .=.338)$, financial industry $(M=2.91, S . D .=.241)$, and technological industry ( $M$ $=2.88$, S.D. $=.377)$ respectively. In addition, the findings indicated that employees with education in crisis management $(\mathrm{M}=3.21, \mathrm{~S} . \mathrm{D} .=.382)$ had the same level of perceived organizational preparedness compared to employees without education in crisis management $(M=2.82$, S.D. $=.286)$.

\section{Conclusion and Discussion}

For research question \#1, results showed that the total mean score of perceived organizational crisis preparedness of respondents was "high." To consider each item from the highest mean scores to the lowest mean scores, the findings indicated that item\#18 "All organization members are required to rehearse portions of our crisis plan, for example, evacuation" was perceived in a very high level. The second highest mean score was item\#16 "I know where the nearest emergency exits are to my desk/ workstation." This finding was consistent to Promsri (2014) who found that the employees in a paper packaging company perceived item\#18 as the highest mean score. This means that purposively selected companies listed in SET 100 in six different industries had the rehearsal like evacuation as part of their crisis management and preparation. For the lowest mean scores, the findings showed that item\#19 "It would be easy for a potentially threatening nonemployee to gain access to my workplace" was perceived "low." The second lowest mean score was item\#5 "In the event of an emergency or disaster, I am familiar with my organization's plan to continue operations from another location. Overall, the results of perceived organizational crisis preparedness showed the readiness of six organizations listed in SET100 to cope with crisis events as the total score was in "high" level. This may be because these organizations had a big market capitalization and large assets, and they needed to ensure that they had had crisis management plan in place for before crisis, during crisis, and after crisis to handle with crisis properly and effectively. Moreover, based on the findings, it seemed that most organizations attempted to rehearse their employee to be ready for confronting with crisis incidents. These findings were consistent with Promsri's (2014) findings.

For research question \#2, findings found that female had the same level of perception of organizational crisis preparedness than male. Top manager had higher perception of organizational crisis preparedness ompared to first-line manager, and non-management, respectively. This was consistent with the findings of Fowler, Kling, and Larson (2007), which indicated that the top management had a higher perception of crisis preparedness than typical employees. Furthermore, respondents who worked at the organization with different number of employees had the same level of perception of organizational crisis preparedness. These findings were inconsistent with Fowler, Kling, and Larson (2007) who found that organizations employed more than 500 employees showed the highest perception of crisis preparedness. This was because these two studies were conducted in the different context in terms of type and size of company. Also, executives had a higher perception of organizational crisis preparedness than the employees. This finding was consistent with Promsri's (2014) findings as he found the significant differences between executives and employees. This study examined the perception of employees of a packaging company in Thailand towards organizational crisis preparedness. This study showed than executives of a packaging company had a greater perception on organizational crisis preparedness than employees. Besides, this present study also found that respondents who held graduate degree had higher perception of organizational crisis preparedness than respondents who earned undergraduate degree and below undergraduate degree, respectively. Additionally, results found that employees with more than 20 years of working experience had the same level of perception of organizational crisis preparedness compared to employees with 1-10 years of working experience, and employees with 10-20 years of working experience, respectively. All of these respondents perception with different working experience towards crisis preparation in the organization were in "high" level, which means that different working experience of respondents did not affect the perception on organizational crisis preparedness. This finding supported the findings of Promsri (2014) as he found no significant differences of perceived organizational crisis preparedness among employees who had the different years of working experience. The finding of this study was inconsistent with Najafbagy's study (2011), which reported that the older mangers were accustomed to 
crisis management, and took crisis events and incidents more critically than younger ones. Among six companies in different industries, results showed that respondents who worked in property and construction industry $(M=3.54$, S.D. = .433) and agriculture industry had higher perception of organizational crisis preparedness than service industry, resource industry, financial industry, and technological industry. This finding was new knowledge in this field, and needed to be explored more in the further study. In addition, the findings indicated that employees with education crisis had the same level of perceived organizational preparedness compared to employees without education crisis. This finding was inconsistent with Promsri's findings (2014), which indicated significant difference between employees for education in crisis, which employees with education crisis had a higher level of perceived organizational preparedness than employees without education crisis.

\section{Limitations and Recommendations for Future Research}

There were some limitations in this research. As this research used a small sample size in different companies in different industries listed in SET100 index using non-probability sample, the results of this study were unable to generalize to other companies or industries listed in SET100. This impacted on the external validity of this study. Thus, to strengthen external validity of the study, the sampling technique must have been changed in the further study to ensure the representativeness of respondents. Some variables such as the number of employees might be deducted for the future study since they may cause some confusion for the respondents. The further study should expand the sample size, and focus on the specific companies in the same industry or various companies in the different industries to compare the differences of perceived organizational crisis preparedness. Inferential statistics must be used to analyze the differences of organizational crisis preparedness among the chosen organizations to find the significant differences between the variables. Besides, even though the validity and reliability of scale measurement in this study were highly acceptable, the exploratory factor analysis and confirmatory factor analysis must be used to reconfirm and remove some variables, and group the dimensions of organizational crisis preparedness. Furthermore, other variables relating to organizational characteristics should be considered for the further study. The comparative study of two or more corporations in the same or different industries about perceived organizational crisis preparedness should be investigated in the future. This would help understand the readiness of each corporation in terms of crisis management and preparedness.

\section{Acknowledgement}

This research was sponsored by Rajamangala University of Technology Phra Nakhon.

\section{References}

Bernstein, J. (2012). Manager's guide to crisis management. Madison, Wl: McGraw-Hill.

Chong, J. (2004). Six steps to better crisis management. Journal of Business Strategy, 25,2. Retrieved from ProQuest Database.

Chong, J. \& Nyaw, M. (2002). Are Hong Kong companies prepared for crisis? Disaster Prevention and Management, 11,1. Retrieved from ProQuest Database.

Dinkin, D. R. (2007). Organizational crises in local North Carolina public health agencies: a crisis typology and assessment of organizational preparedness. Unpublished doctoral dissertation, North Carolina, U.S.A. Retrieved on February 7, 2014 from UMI ProQuest Digital Dissertation.

Fowler, K. L., Kling, N. D., \& Larson, M. D. (2007). Organizational preparedness for coping with a major crisis or disaster. Business and Society, 46,1. Retrieved from ProQuest Database.

Johansen, W., Aggerholm, H. K., \& Frandsen, F. (2012). Entering new territory: a study of internal crisis management and crisis communication in organizations. Public Relation Review, 38. Retrieved from ProQuest Database.

Najafbagy, R. (2011). The crisis management capabilities and preparedness of organizations: a study of Iranian Hospitals. International Journal of Management, 28,2. Retrieved from ProQuest Database.

Ocal, E., Oral, E. L., \& Erdis, E. (2006). Crisis management in Turkish construction industry. Building and Environment, 41, 1498-1503.

Promsri, C. (2014). Thai employees' perception towards organizational crisis preparedness. Mediterranean Journal of Social Sciences, $5,14,41-51$.

Stock Exchange of Thailand. (2007). Index Rules for SET 50 Index 100 Index. retrieved from http://www.set.or.th/en/products/index/files ISET50100_Selection_Criteria_EN.pdf 